smell of the entrails of a froshly killed animal, pointed in the sarne direction."

There is nothing in all this to make out a plausible case for the assumption of a now substance called 'teleplasm ' or 'ectoplasm.' It is impossible to extract from the literature on the subject any consistent description of its supposed properties. In the days of Katic King, the apparition was able to cut off portions of her dress and distribute them to her audience, who found that they resembled ordinary calico. Nowadays the substance is supposed to be very fugitive and sensitive to light. The hypothesis which seems to cover all the facts is that a succession of mediums, under pressure from sitters anxious to see marvels, have produced these 'spirit forms' by trickery. This trickery has become increasingly difficult and has practically disappeared whenever test conditions are applied. It is, thercfore, impossible to admit the existence of any new facts, and cven a tentative explanation of them is uncalled-for. Science might just as well concern itself with the anatomy and physiology of fairics.

There is another matter which must not be overlooked. The forces behind occultism and supernaturalism are very powerful. They are based upon the very human craving for the mar- vellous. All religions contain this element, and promote it in various ways. There is a tendency in modern times, especially in America, to link religion with science, so as to utilise the growing prestige of the latter. The funds available for the enterprise of winning the approval of science for the modern miracle are very considerable. A wealthy French spiritualist recently established and endowed an International Metapsychic Institute in Paris, and appointed as its director a local practitioner of spiritualistic sympathies, Dr. Gustave Geley. The publication of his conclusions and speculations in an imposing and expensive volume formed a very telling piece of propaganda.

Such institutions form a kind of spearhead forged by occultism for piercing the armour of science, and it would not be surprising to see the foundation in England of an Imperial Academy of Natural and Supernatural Science, generously endowed from British and American sources. Its prospectus would be liberally sprinkled with the names of Crookes, Lombroso, Richet, Flammarion, Geley, Crawford, and von Schrenck-Notzing, and everybody would know that soience had at last become 'spiritualised' and centred in other worlds than ours; and sacerdotalism, having been expelled by the door, would come back through the window.

\title{
Base Exchange and the Formation of Coal.
}

By Dr. E. MoKenzie TaYlor.

$\mathrm{D}^{2}$ URING a soil survey of the northern portion of the Nile Delta for reclamation purposes, a deposit of vegetable debris was discovered at a depth of two metres below the soil surface. As this deposit was found to contain peat, fusain, and partially fusainised material, an association that does not appear to have been recorded previously, it appeared that an investigation of tho conditions under which the deposit existed might afford evidence of the mode of formation of coal. It is accepted that coal has been formed from vegetable material, and it has been generally assumed that the vegetable material accumulated as peat. The connexion between peat and coal has, however, not been established.

An examination of the soil overlying the vegetable layer in Egypt showed that it was alkaline and that the principle replaceable base present was sodium. The soil had originally been formed by the deposition of Nile silt in which the main replaceable base is calcium. The conditions under which the soil was situated showed that the conversion of the calcium-clay in the Nile silt into sodium-clay had taken place as the result of base exchange with sodium chloride solutions, and that the alkalinity had been produced by the subsequent hydrolysis of the sodium-clay in fresh water. Investigations in the laboratory have shown that it is possible to maintain the alkalinity of a medium for a considerable length of time by the hydrolysis of sodium-clay. It has also been shown that a roof containing hydrolysing sodiumclay is impermeable to gases and water, that the conditions under such a roof are anaerobic, and that the alkaline medium produced under such a roof is suitable for the continuous bacterial decomposition of organic matter.

A study has been made of the bacterial decomposition of organic materials under the alkaline anaerobic conditions furmished by a roof containing sodium - clay. Sugars, starch, and cellulose decomposed under these conditions yield gaseous products only, the gas produced accumulating beneath the roof. An examination of this gas showed that it was principally mothane, the carbon dioxide produced during the decomposition having been absorbed by the sodium hydrate resulting from the hydrolysis of the sodium-clay. Mature leaves were submitted to bacterial decomposition under a sodium-clay roof. The residual solid product was black and possessed the typical fusain structure. Analyses of the leaves at intervals showed that elimination of oxygen was taking place and that the process of decomposition was continuous. The bacterial decomposition of peat under a roof containing sodium-clay was also investigated. It was found that peat could be decomposed under the alkaline anaerobic conditions, that the alkali-soluble 'humus' in the peat was removed in solution from the seat of the bacterial action, and that the gas accumulating under the alkaline roof was methane. The investigation of the bacterial decomposition of organic materials under a roof containing sodium-clay has shown that bacterial activity in the continuously alkaline medium is not inhibited by the accumulation of toxic products of the decomposition and that the solid residue is a reduction product. It has also

No. 3021, VoL. 1207 
shown that peat can be decomposed under alkaline anaerobic conditions.

As peat can be decomposed by bacteria under an alkaline roof, and as vegetable material decomposed in such a situation yields a solid reduction residue with a fusain structure, the occurrence of a peat deposit containing fusain under an alkaline soil points to the conclusion that fusain is a decomposition product of peat under the alkaline anaerobic conditions imposed by a roof containing hydrolysing sodium-clay.

Since fusain is a constituent of bituminous coal, it seemed probable that bituminous coal might have resulted from the bacterial decomposition of vegetable material under alkaline roof conditions. A considerable number of specimens of the roofs of coal seams in Great Britain were examined, and it was found that the great majority were alkaline and that sodium was the main replaceable base present. The exceptions to these rules were of two main types: $(a)$ coarse-textured shales or black sandstones, and $(b)$ white sandstones and conglomerates. The final result of the hydrolysis of sodium-clay is the production of an unsaturated clay with an acid reaction. If the amount of reactive clay present in the roof was originally small, complete hydrolysis is likely to have taken place under fresh-water conditions with the formation of an unsaturated residue with an acid reaction. The coarse - textured shales and black sandstones would contain comparatively little reactive clay material, and hence the sodium compound would be liable to complete hydrolysis. The first exception is apparently due to the complete hydrolysis of the sodium-clay originally present. The second type of exception is of local occurrence only and is usually in the nature of a wash-out, indicating that the sandstone or conglomerate is not the original roof of the seam. Frequently the sandstone is underlain by a thin shale layer. From a consideration of the results, it appears that the original roofs of bituminous coal seams have undergone base exchange with sodium chloride solutions, and that afterwards the sodiumclay has undergone hydrolysis in fresh water.

An examination of the roofs of the anthracite coal seams of South Wales has shown that they are also alkaline and contain sodium-clay, indicating that the anthracite in the South Wales coalfield has been formed under similar final conditions to bituminous coal.

The results of these investigations point to the conclusion that bituminous coal has been formed as the result of the bacterial decomposition of vegetable residues under the alkaline anaerobic conditions imposed by a roof which has undergone base exchange with sodium chloride solution and subsequent hydrolysis of the sodium-clay in fresh water.

An examination of the roofs of a number of lignite seams has also been made. It appears that the main replaceable base present in the roofs of lignite seams is calcium, indicating that the roofs of these seams have not undergone base exchange with solutions of sodium chloride. Lignite is therefore not necessarily an intermediate product between vegetable matter and bituminous coal, but is rather a decomposition product of vegetable matter under a roof containing calcium-clay.

As bituminous coals and anthracite occur in different parts of the same seam and under the same roof conditions, it is suggested that the difference in the final decomposition productsbituminous coal and anthracite - is due to differences in the material submitted to bacterial decomposition under the final alkaline anaerobic conditions. It is not necessary to assume differences in the original plant materials to account for this. Differences in the decomposition products during the 'peat stage' may have arisen due to variations in the conditions of the first decom position. This would result in a variety of products being submitted to the final decomposition under alkaline anaerobic conditions giving rise to the variety of final products composing the bituminous coal-anthracite series.

Base exchange between sedimentary deposits and solutions of sodium chloride can take place under three conditions in Nature: (a) by deposition of the silt in sea water, $(b)$ by submergence in sea water of a deposit already formed, and $(c)$ by the reaction of the clay with capillary solutions of sodium chloride raised from a water-table containing that salt. Geological evidence of base exchange under conditions (a) and (b) will be positive. Under condition (c) there will be no geological evidence of base exchange, determinations of the $p \mathrm{H}$ value and the nature of the replaceable bases being the only evidence on which to base a conclusion. From the examination of the roofs of the coal seams in Great Britain, it appears that the majority of the roofs have undergone base exchange with capillary solutions of sodium chloride.

The presence of the alkaline roof satisfactorily accounts for the observation that coal seam gases mainly consist of methane. Oxygen elimination from the vegetable material must have taken place during coal formation, but no appreciable quantity of carbon dioxide has becn recorded in coal seam gases. The carbon dioxide produced by the oxygen elimination would be absorbed in the sodium hydrate solution resulting from the hydrolysis of the sodium-clay leaving a methane residue.

Three main conclusions concerning the formation of coal may be drawn as a result of this investigation:

(1) The vegetable material accumulated as peat.

(2) The roofs of bituminous and anthracite coal seams have undergone base exchange with sodium chloride solutions, the sodium-clay being afterwards hydrolysed in fresh water. 'This would provide an alkaline medium under anaerobic conditions for the bacterial decomposition of peat.

(3) The decomposition of peat under a roof containing calcium-clay results in lignite formation.

The roofs of bituminous coal seams other than those of the Carboniferous System are being investigated. The results so far obtained indicate that base exchange between the roof and sodium chloride solutions is common to all bituminous coal searns and forms the connecting link between the coal seams of the various geological formations.

No. 3021 , VoL. 120] 